\section{A Colorimetric Method for the Estimation of Nicotinic Acid in Foodstuffs}

RECENT investigations ${ }^{1,2,3,4}$ have shown that pellagra in human beings, black-tongue in dogs and pellagra-like symptoms in pigs, can be cured by the administration of nicotinic acid, and nicotinic acid is probably identical with, or a precursor of, the pellagra. preventive (P.-P.) factor. Hence the question of estimating the nicotinic acid content of foodstuffs is of immediate importance and interest.

A method has been developed based on the colour produced by the pyridine ring ${ }^{5}$ when acted upon by cyanogen-bromide and aniline. A hot aqueous extract of the test foodstuff is freed from protein derivatives by lead acetate, the excess of lead being removed by sulphuric acid; the extract is brought to $p \mathrm{H} 10$ and any colour present is removed by boiling with charcoal. The clear colourless extract is adjusted to $p \mathbf{H} 7 \cdot 5$ and made up to volume.

Aliquot portions of the extract and the standard nicotinic acid solution are each diluted with water to the same volume $(20-30 \mathrm{ml}$.) in $100 \mathrm{ml}$. separating funnels ; $4 \mathrm{ml}$. of freshly prepared aqueous cyanogenbromide solution is then added to each and the mixture shaken and allowed to stand for half an hour. $4 \mathrm{ml}$. of a saturated aqueous aniline solution is then added and the mixture again shaken. The yellowish-green colour produced is then extracted three times with $10 \mathrm{ml}$., $5 \mathrm{ml}$. and $5 \mathrm{ml}$. portions of purified amyl alcohol ${ }^{5}$ and the colours compared after standing for two hours.

The method is extremely sensitive- $0.01 \mathrm{mgm}$. of nicotinic acid is easily detected - and the gradation of the colour produced is excellent for increments of $0.01 \mathrm{mgm}$. up to $0.1 \mathrm{mgm}$. of nicotinic acid. The whole procedure is simple.

The method has been applied to twelve foodstuffs. Further, known amounts of nicotinic acid were added to known amounts of yeast and raw milled rice and the recovery was good in both cases. The results are shown in Tables $I$ and II.

TABLE 1 .

\begin{tabular}{|c|c|c|c|c|}
\hline \multicolumn{4}{|c|}{ Name of Foodstuff } & $\frac{\begin{array}{c}\text { Nicotinic acid } \\
(\mathrm{mgm} . \%)\end{array}}{62 \cdot 50}$ \\
\hline $\begin{array}{l}\text { Yeast, dried (brewer's) } \\
\text { Skimmed milk powder } \\
\text { Wheat, whole .. } \\
\text { Ragi (Eleusine coracana) } \\
\text { Rice, raw, milled } \\
\text { Rice, parboiled, home-pound } \\
\text { Cambu (Pennisetum typhoide } \\
\text { Cholam (Sorghum vulgare) } \\
\text { Maize, white .. .. } \\
\text { Soya bean } \\
\text { Red gram (Cajanus indicus) } \\
\text { Bengal gram .. .. }\end{array}$ & 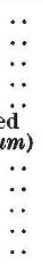 & $\begin{array}{l}\ldots \\
\ldots \\
\cdots \\
\cdots \\
\cdots \\
\cdots \\
\cdots \\
\cdots\end{array}$ & $\begin{array}{l}\ldots \\
\cdots \\
\because \\
\cdots \\
\cdots \\
\cdots \\
\cdots \\
\cdots\end{array}$ & $\begin{array}{r}62 \cdot 50 \\
10 \cdot 53 \\
5 \cdot 33 \\
3 \cdot 08 \\
2 \cdot 38 \\
2 \cdot 78 \\
2 \cdot 50 \\
1 \cdot 82 \\
1 \cdot 48 \\
4 \cdot 85 \\
5 \cdot 33 \\
4 \cdot 74\end{array}$ \\
\hline
\end{tabular}

\begin{tabular}{|c|c|c|c|} 
TABLE II. \\
\hline $\begin{array}{c}\text { Foodstuff }+ \\
\text { nicotinic acid }\end{array}$ & $\begin{array}{c}\text { Total nicotinic } \\
\text { acid present } \\
(\mathrm{mgm} . \%)\end{array}$ & $\begin{array}{c}\text { Total nicotinic } \\
\text { acid found } \\
(\mathrm{mgm} . \%)\end{array}$ & $\begin{array}{c}\text { Error } \\
\%\end{array}$ \\
\hline $\begin{array}{c}\text { Raw milled rice } \\
10 \text { gm. }+1 \text { mgm. } \\
\text { nicotinic acid. }\end{array}$ & $1 \cdot 24$ & $1 \cdot 29$ & 5 \\
\hline $\begin{array}{c}\text { Dried yeast } \\
\text { 10 gm. }+10 \mathrm{mgm} . \\
\text { nicotinic acid. }\end{array}$ & $16 \cdot 25$ & $15 \cdot 85$ & -4 \\
\hline
\end{tabular}

The colour reaction is probably given by all com. pounds containing the pyridine ring, and the assumption is made that nicotinic acid and its derivatives form the major portion of such compounds in most common foodstuffs. Further work is being undertaken to verify this point.

The low value of maize is particularly interesting, because of the association between pellagra and maize. While true pellagra is rare in India, a pellagralike condition (stomatitis) is extremely common, and it is quite possible that deficiency of nicotinic acid is an important defect of Indian diets based on rice or millet.

Nutrition Research Laboratories,

Indian Research Fund Association, Coonoor,

March 7.

${ }^{1}$ Fouts, Helmer, Lepkovsky and Jukes, Proc. Soc. Exp. Biol. Med., 37, 405 (1937).

2 Smith, Ruffin and Smith, J. Amer. Med. As8oc., 109, 2054 (1937).

$s$ EIvehjem, Madden, Strong and Woolley, J. Amer. Chem. Soc., 59, 1767 (1937).

Chick, Macrae, Martin and Martin, Biochem. J., 32, 10 (1938).

$\checkmark$ Strafford and Parry-Jones, Analyst, 58, 380 (1933).

\section{Selective Oxidation as a Fundamental Principle in Metallic Protection}

IT is known that the oxidation or tarnishing of iron and copper can sometimes be diminished by alloying with small amounts of aluminium, beryllium, chromium and silicon, and that some oxide films confer protection or even passivity - especially when they are so thin as to be invisible. Little has been done, however, to obtain reliable protection by controlling the composition of the films. Miyake ${ }^{1}$ has noted that, in the case of copper containing more than 3 per cent aluminium, the oxygen content of the atmosphere used for the first heating is an important factor. Sloman ${ }^{2}$ has recommended the introduction of beryllium into silver to prevent tarnishing, but the efficacy of this addition has been questioned by Raub ${ }^{3}$, whose work suggests to us that some factor other than the composition of the alloy determines its behaviour.

A new derivation ${ }^{4}$ of Wagner's expression ${ }^{6}$ $\left(n_{1}+n_{2}\right) n_{3} x E / F$ for the velocity constant of tarnishing or oxidation reactions following the parabolic law (where $x$ is the electrical conductivity of the reaction product, $n_{1}, n_{2}$ and $n_{3}$ the transport numbers of cations, anions and electrons respectively in the film and $E_{0}$ the affinity of the reactants for each other) has suggested the necessity of producing on the metal to be protected a film of very low conductivity. Alumina or beryllia will possess the required properties if pure; but the analogous case of silver chloride con. taining traces of cadmium chloride ${ }^{6}$ considered in connexion with the work on the conductivity of alumina? ${ }^{2}$, suggests that small traces of silver or copper oxides in the alumina or beryllia film would greatly increase the conductivity, and therefore the rate of tarnishing or oxidation.

By pre-treating alloys containing aluminium or beryllium in a controlled atmosphere-designed to permit the oxidation of the alloying constituent only and at temperatures suitable for the necessary diffusion of this constituent to the surface-protective films of pure alumina and beryllia have been obtained in these laboratories. Application of this principle of selective oxidation has led to materials almost immune from 'tarnishing' and 'scaling'. A specimen of copper containing 5 per cent aluminium heated in air at $800^{\circ} \mathrm{C}$. for four hours gained $50 \mathrm{mgm}$./sq. dm., 